\title{
Daya dan Emisi Jelaga dari Mesin Diesel Berbahan Bakar Solar-Jatropa-Buthanol
}

\author{
Syarifudin $^{1 *}$ dan Syaiful \\ ${ }^{1}$ Program Studi Teknik Mesin, Politeknik Harapan Bersama, \\ Jl. Mataram No.9, Pesurungan Lor, Kec. Margadana, Kota Tegal, Jawa Tengah \\ ${ }^{2}$ Departemen Teknik Mesin, Universitas Diponegoro, \\ J1. Prof. Soedarto No.13, Tembalang, Kota Semarang, Jawa Tengah \\ *E-mail: Masudinsyarif88@gmail.com
}

Diterima: 29-07-2019; Direvisi: 04-12-2019; Dipublikasi: 31-12-2019

\section{Abstrak}

Peningkatan jumlah kendaraan bermotor membuat kebutuhan bahan bakar fosil dan emisi gas buang meningkat. Jatropa banyak diteliti untuk mengganti bahan bakar karena memiliki karakteristik yang mendekati solar. Selain jatropa, kandungan oksigen yang tinggi dan viskositas yang rendah dalam energi terbarukan butanol dianggap mampu menurunkan permasalahan mesin diesel. Penelitian ini mengobservasi penggunaan bahan bakar campuran solar-jatropa-butanol terhadap daya dan smoke opacity mesin diesel 4JB1. Pengujian dilakukan pada putaran konstant $2500 \mathrm{rpm}$. Persentase campuran bahan bakar antara solar/jatropa/butanol sebesar 85/10/5, 80/10/10, 75/10/15, $75 / 20 / 5,70 / 20 / 10,65 / 20 / 15,65 / 30 / 5,60 / 30 / 10,55 / 30 / 15$ berbasis volume. Hasil pengujian memperlihatkan bahwa penggunaan bahan bakar campuran solar-jatropa-butanol menghasilkan daya dan smoke opacity yang lebih rendah dibandingkan solar.
\end{abstract}

Kata kunci: daya; emisi jelaga; mesin diesel; jatropa; butanol

\begin{abstract}
The growing amount of motor vehicle caused increasing of fossil based fuel demand and exhaust emission. Jatropa is widely researched to replace fuel because it has characteristics that are close to diesel. Aside from jatropa, high oxygen content and low viscosity in renewable energy butanol are considered capable of reducing diesel engine problems. This research observes the use of diesel-jatropa-buthanol mixture fuel to the power and smoke opacity of a 4JB1 diesel engine. Tests carried out at a constant speed of $2500 \mathrm{rpm}$. The fuel mix percentageof solar/jatropa/buthanol is 85/10/5, 80/10/10, 75/10/15, 75/20/5, 70/20/10, 65/20/15, 65/30/5, 60/30 / 10, 55/30/15 based on volume. The test results show that the use of diesel-jatropa-butanol mixed fuel produces power and smoke opacity lower than diesel fuel.
\end{abstract}

Keywords: power; smoke opacity; diesel engine; jatropa; buthanol

\section{Pendahuluan}

Pertumbuhan volume kendaraan mengakibatkan peningkatan kebutuhan bahan bakar fosil dan emisi gas buang kendaraan. Menurut Badan Pusat Statistika, peningkatan volume kendaraan tahun 2015 sampai tahun 2017 sangat drastis sebesar 52\% [1]. Kendaraan berpenggerak mesin diesel adalah penyumbang terbesar peningkatan volume kendaraan. Mesin diesel dipilih karena tingginya efisiensi bahan bakar dan daya tahan mesin serta karakterisik yang andal dibandingkan mesin bensin [2]. Selain itu, pada sisi pembakaran mesin diesel tidak memerlukan pengontrolan bunga api sehingga memudahkan fleksibelitas jenis bahan bakar yang digunakan [3].

Jatropa adalah bahan bakar alternatif yang dapat dijadikan solusi peningkatan kebutuhan bahan bakar fosil. Jatropa memiliki cetane number yang hampir sama dengan solar. Jatropa diproduksi dari tanaman yang tidak dikonsumsi manusia sehingga harganya relatif murah [4]. Menurut Gomaa, Alimin, \& Kamarudin, efisiensi mesin diesel menjadi lebih rendah dan emisi jelaga menjadi lebih tinggi ketika menggunakan bahan bakar jatropa [5]. Rendahnya nilai kalor dan tingginya viskositas dalam jatropa menyebabkan penurunan temperatur ruang bakar sehingga tekanan kerja indikasi menurun untuk menghasilkan day [6].

Butanol merupakan jenis alkohol tinggi kandungan oksigen dan rendah viskositas. Butanol juga memiliki cetane number yang mendekati solar. Menurut Ibrahim, penambahan butanol dalam bahan bakar biodiesel memperbaiki nilai 
torsi dan daya meskipun masih lebih tinggi solar [7]. Kandungan oksigen yang tinggi dalam butanol menyebabkan penundaan pengapian lebih lama dan menghasilkan tekanan puncak yang lebih baik [8]. Selain itu, kandungan oksigen yang tinggi dalam butanol membantu proses oksidasi yang lebih baik sehingga dapat menekan pembentukan jelaga [2].

\section{Material dan metodologi}

Penelitian dilaksanakan di Laboratorium Thermofluida Universitas Diponegoro Semarang. Pengujian ini bertujuan untuk mengobservasi karakteristik daya dan emisi jelaga. Adapun teknis pengujian terpapar pada gambar 1. skema sistem pengujian. Pengujian menggunakan mesin diesel Isuzu 4jB1, 4 silinder, 4 langkah 2800 cc dengan putaran konstant $2500 \mathrm{rpm}$. Bahan bakar yang digunakan adalah campuran solar, jatropa dan butanol. Volume jatropa yang digunakan sebesar 10\%, 20\% dan 30\% berbasis volume, sedangkan butanol yang digunakan sebesar 5\%, 10\%, 15\% berbasis volume. Karakteristik bahan bakar tercantum pada tabel 1. Bahan bakar dicampur dan diaduk menggunakan mixer agar menjadi homogen.

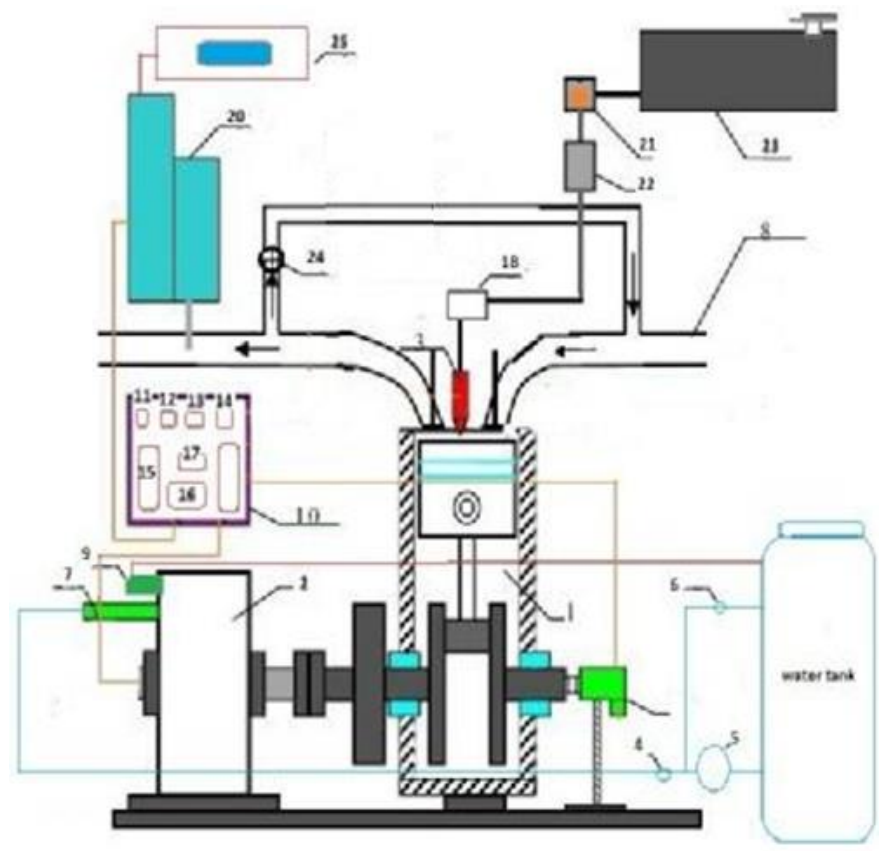

Gambar 1. Skema sistem pengujian

Tabel 1. Karakteristik bahan bakar

\begin{tabular}{clccc}
\hline \multicolumn{1}{c}{ Properties } & Solar & Jatropa & Butanol \\
\hline No. & & 48 & 41.8 & 23.4 \\
2 & Angka Setana & 0.05 & 3.16 & 34.22 \\
3 & Kadar Air (\%V) & $2.0-5.0$ & 3.23 & 2.05 \\
4 & Viskositas pada Suhu $40^{\circ} \mathrm{C}($ Mpa.s) & 45.21 & 37.97 & 33.21 \\
5 & Kandai Kalor (MJ/kg) & - & 10.9 & 21.69 \\
6 & Titik Nyala $\left({ }^{\circ} \mathrm{C}\right)$ & 60 & 198 & 38 \\
\hline
\end{tabular}

\section{Hasil dan Pembahasan}

\subsection{Daya mesin diesel berbahan bakar solar-jatropa-butanol}

Gambar 2 adalah presentasi hasil pengujian daya mesin diesel 4JB1 dengan bahan bakar solar-jatropa-butanol. Penggunaan bahan bakar campuran menghasilkan daya yang lebih rendah dibandingkan dengan solar murni. Rendahnya nilai kalor dari bahan bakar campuran mempengaruhi karakteristik pembakaran [9; 7]. Semakin besar kandungan butanol nilai daya semakin mendekati bahan bakar solar murni. Hal ini akibat kandungan oksigen yang tinggi dalam butanol menyebabkan punundaan pengapian yang lama dan menghasilkan tekanan puncak yang lebih baik 
sehingga memperbaiki karakteristik pembakaran. Penurunan nilai daya tertinggi terjadi pada bahan bakar dengan kandungan jatropa $30 \%$ dan butanol $5 \%$ yaitu sebesar 6,27\% dibandingkan D100.

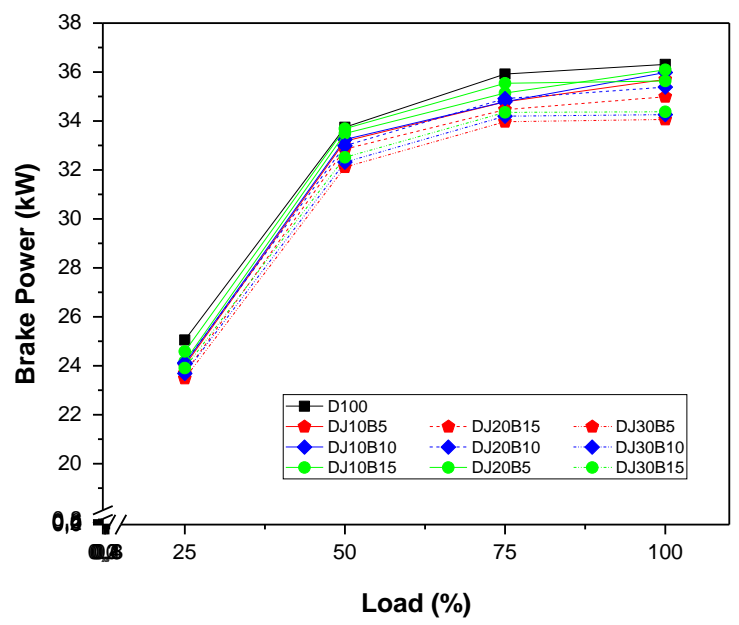

Gambar 2. Hasil pengujian daya mesin diesel berbahan bakar solar-jatropa-butanol

\subsection{Emisi jelaga mesin diesel berbahan bakar solar-jatropa-butanol}

Gambar 3 mempresentasikan hasil pengujian smoke opacity (emisi jelaga) mesin diesel dengan bahan bakar campuran solar-jatropa-butanol. pengujian dengan bahan bakar campuran menghasilkan persentase smoke opacity yang lebih rendah dibandingkan solar murni. Kandungan oksigen yang tinggi dalam bahan bakar campuran mengurangi pembentukan emisi jelaga [2]. Kadar oksigen yang tinggi dalam bahan bakar campuran memicu terjadinya oksidasi karbon yang mengakibatkan smoke opacity menurun. Penurunan smoke opacity tertinggi terjadi pada bahan bakar dengan kandungan jatropa $30 \%$ dan butanol $15 \%$ yaitu sebesar 31,03\% dibandingkan D100.

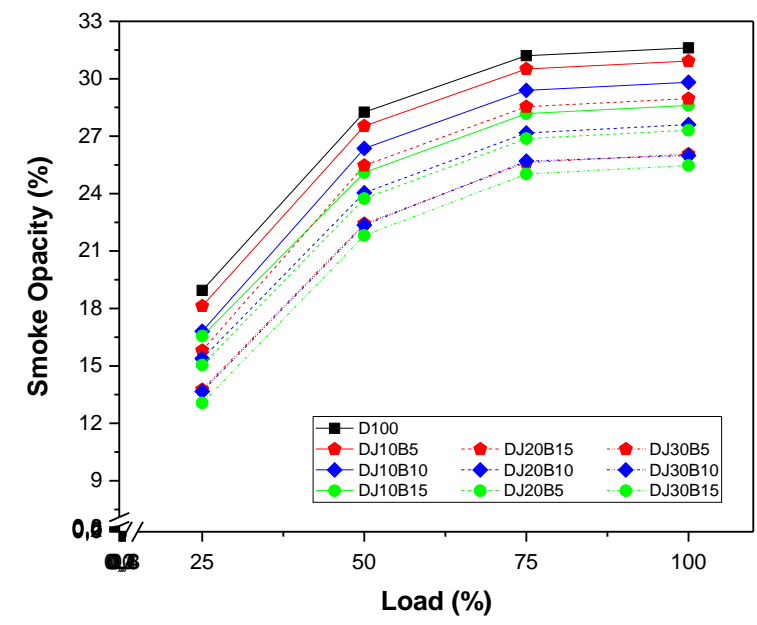

Gambar 3. Hasil pengujian emisi jelaga mesin diesel berbahan bakar solar-jatropa-butanol

\section{Kesimpulan}

Berdasarkan kajian penggunaan bahan bakar campuran solar-jatropa-butanol terhadap daya dan emisi jelaga berdampak sebagai berikut: Nilai daya cenderung lebih rendah dibandingkan solar murni. Semakin besar kandungan jatropa semakin rendah nilai daya. Penurunan ini terjadi akibat rendahnya nilai kalor dalam bahan bakar campuran. 
Emisi jelaga yang diindikasikan dengan smoke opacity pada penggunaan bahan bakar campuran solar-jatropa-butanol terjadi penurunan. Semakin besar porsentase bahan bakar campuran semakin tinggi penurunan nilai smoke opacity.

\section{Daftar Pustaka}

[1] Badan Pusat Statistik. Perkembangan Jumlah Kendaraan Bermotor Menurut Jenis. https://www.bps.go.id/linkTableDinamis/view/id/1133. BPS: Indonesia; 2017 [Diakses pada tanggal 11 November 2019]

[2] Huang H., Liu Q., Teng W., Wang Q. The potentials for improving combustion performance and emissions in diesel engines by fueling nbutanol/diesel/PODE3-4 blends. Energy Procedia. 2017; 105: pp. 914-920.

[3] Purwatama K.U.A., dan Syaiful. Performa dan Emisi Jelaga dari Mesin Diesel pada Putaran Rendah dengan menggunakan Bahan Bakar Campuran Biosolar dan Metanol Kadar Rendah. Indonesia: Universitas Diponegoro; 2014.

[4] Darmana E., Syaiful, Fajar B. Pengaruh Cold EGR terhadap Daya pada Mesin Diesel dengan Bahan Bakar Campuran Solar dan Jatropa. Eksergi Jurnal Teknik Energi. 2013; 9(03): p.40.

[5] Gomma, M., Alimin, A.J., Kamarudin, K.A. The effect of EGR rates on NOX and smoke emissions of an IDI diesel engine fuelled with Jatropha biodiesel blends. Energy and Environment. 2011 Januari; 2(03): p. 477-490.

[6] Heywood, John B.L. Internal Combustion Engine Fundamentals. United States: McGraw-Hill, Inc; 1988.

[7] Ibrahim Amr. Performance and Combution Characteristics of a diesel engine fuelled by butanol-biodiesel-diesel blends. Applied Thermal Engineering. 2016; 103: p. 651-659.

[8] Isak M.Z., Bayindir H., Iscan B., Aydin H. The Effect of n-butanol additive on low load combution, performance and emissions of biodiesel-diesel blend in a heavy duty diesel power generator. Journal of the Energy Institute. 2017; 90: p. 174-184.

[9] Ileri E., Atmanli A., Yilmaz N. Comparative Analyses of n-Butanol Erapeseed Oilediesel Blend with Biodiesel, Diesel and Biodiesel diesel Fuels in a Turbocharged Direct Injection Diesel Engine. Journal of the Energy Institute. 2016; 89: p. 586-593. 